ENTREPRENEURSHIP AND SUSTAINABILITY ISSUES

ISSN 2345-0282 (online) http://jssidoi.org/jesi/

2021 Volume 8 Number 4 (June)

http://doi.org/10.9770/jesi.2021.8.4(23)

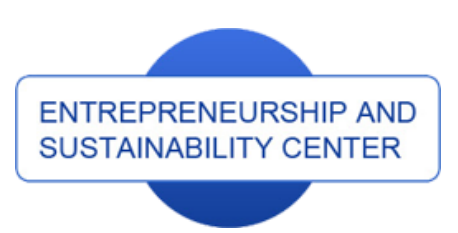

enterprise

europe

network

Publisher

Business Support on Your Doorstep

CASPA

http://jssidoi.org/esc/home

Clarivate

Analytics

\title{
CORE FEATURES FOR THE DESIGN OF REMUNERATION SYSTEMS FOR SUSTAINABLE HUMAN RESOURCE MANAGEMENT DURING THE COVID-19 PANDEMIC: POLISH COMPANIES EXPERIENCES *
}

\section{Hanna Kinowska}

Collegium of Business Administration, SGH Warsaw School of Economics, al. Niepodległości 162, 02-554 Warsaw, Poland

E-mail: hanna.kinowska@sgh.waw.pl

Received 4 February 2021; 2 April 2021; published 30 June 2021

\begin{abstract}
Fulfilling the objectives of sustainable development aimed at combining economic, social and ecological objectives is supported by the concept of Sustainable Human Resource Management (SHRM). SHRM practices enable the maintenance, renewal and restoration of human resources. The article fills a research gap on the characteristics of remuneration systems in SHRM. The purpose of this study is to reveal the remuneration practices that allow organisations to implement sustainable human resource management's characteristics in the COVID-19 crisis. The research uses qualitative data from Polish organisations collected through semi-structured interviews with 15 managers responsible for human resource management (HRM). It shows a diversity of remuneration practices during the COVID-19 crisis such as focusing the remuneration systems on the long-term goals of the organisation and combining social goals with business pragmatism.
\end{abstract}

Keywords: sustainable HRM; remuneration system; COVID-19

\footnotetext{
* This research was carried out within the framework of the Statutory Research for 2019-2021 of the Collegium of Business Administration, SGH Warsaw School of Economics "Enterprise in the face of sustainable development requirements".
}
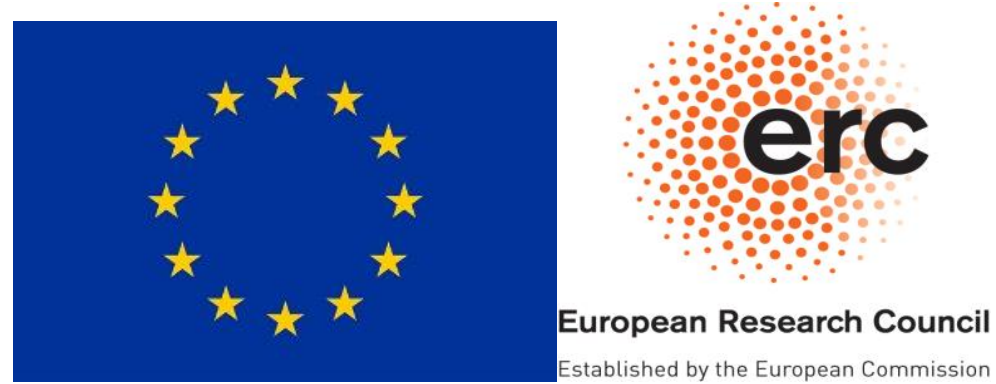


\title{
ENTREPRENEURSHIP AND SUSTAINABILITY ISSUES
}

ISSN 2345-0282 (online) http://jssidoi.org/jesi/

2021 Volume 8 Number 4 (June)

http://doi.org/10.9770/jesi.2021.8.4(23)

\begin{abstract}
Reference to this paper should be made as follows: Kinowska, H. 2021. Core features for the design of remuneration systems for sustainable human resource management during the covid-19 pandemic: Polish companies' experiences, Entrepreneurship and Sustainability Issues, 8(4), 389-402. http://doi.org/10.9770/jesi.2021.8.4(23)
\end{abstract}

JEL Classifications: M52, M54, Q56

Additional disciplines: ecology and environment

\section{Introduction}

Implementing sustainable development concepts - including functioning in the long term and taking into account economic, social and environmental objectives - requires coherent organisational management. Human Resources (HR) play a key role here. The concept of Sustainable human resource management (SHRM) is present in the literature (Diaz-Carrion, López-Fernández, \& Romero-Fernandez, 2018; Ehnert \& Harry, 2012). Pioneering research is emerging to reveal the characteristics of SHRM functions (Stankevičiute \& Savanevičiene, 2018). One of the researchers' views is that the development of personal functions does not keep pace with changes in the work environment (Juchnowicz, 2019). Therefore, the solutions applied are not consistent with organisational aspirations within sustainable development.

Due to their impact on employee behaviour, remuneration systems play a key role in shaping the basis for work that supports sustainable development objectives. Its effectiveness is affected by the employer's consistent application of rules and practices adequate to the adopted strategy. The coherence and consistency of the solutions applied are verified in crises. For instance, as a result of the crisis caused by the COVID-19 pandemic, changes in the functioning of businesses pose challenges to maintaining SHRM rules. Only organisations that have an established track record of sustainable development can maintain consistency even in difficult circumstances resulting from the volatility of the environment. By applying consistent rules, they attract and engage valuable employees and encourage their development and efficiency gains. Lack of knowledge of SHRM's supporting principles can lead to the disruption of an organisation, hence the need for up-to-date research on the characteristics of remuneration systems in sustainable human resource management.

The research gap in the literature boils down to the lack of analysis of the characteristics of remuneration systems supporting SHRM. Only pioneering observations are present (Radvila \& Šilingienè, 2020), though the need for remuneration analyses in the SHRM is an area that requires further analysis (Ehnert \& Harry, 2012; Westerman, Rao, Vanka, \& Gupta, 2020).

The purpose of this paper is to analyse the characteristics of remuneration systems supporting sustainable management using the COVID-19 crisis as a case study. The analysis was carried out based on a critical literature review and exploratory qualitative research. The article broadens the knowledge of SHRM's remuneration systems and supports the popularisation of this model in the practices of organisations.

\section{Theoretical background}

\section{Remuneration systems in sustainable human capital management}

The literature on the relationship between remuneration systems and sustainable HRM is theoretically and empirically inadequate (Radvila \& Šilingienè, 2020). In the SHRM analysis, remuneration issues are addressed in a piecemeal fashion and limited to the integration of environmental initiatives into pay systems. Given the impact of remuneration schemes on workers' behaviour, its link to the sustainable development strategy requires an approach that accounts for all three dimensions: economic, social and environmental. 


\section{ENTREPRENEURSHIP AND SUSTAINABILITY ISSUES}

ISSN 2345-0282 (online) http://jssidoi.org/jesi/

2021 Volume 8 Number 4 (June)

http://doi.org/10.9770/jesi.2021.8.4(23)

The economic dimension of SHRM implements system solutions that allow for achieving high work efficiency at the individual, team and organisational level (Poškiene, 2014). Despite numerous publications, this remains a highly-reviewed discourse for researchers (Guest, 2011). The above trend includes analyses of remuneration schemes in relation to the elements that make up their structure. Some concepts are comprehensive (Armstrong \& Taylor, 2017; Milkovich, Newman, \& Gerhart, 2014; Radvila \& Šilingienè, 2020; Wang, Zhao, \& Thornhill, 2015). There is a consensus on the need for strategic action in the development of remuneration policy (Lawler, 1990), on drawing comparisons between remuneration to company culture, values and objectives (Flannery, Hofrichter, \& Platten, 1996) and work effects and behaviours of employees in line with the organisation's objectives (Schuster \& Zingheim, 1992) taking into account the principles of fairness by considering employee's contribution to the organisation (Juchnowicz, 2012).

Remuneration is an important factor in the concept of socially responsible HRM found in the literature, due to growing appreciation of the social dimension of SHRM. It involves creating a working environment in which employees achieve their professional goals while implementing the company's strategy. It is comprised of fair remuneration adequate to the employee's work engagement and comprehensive benefits (Pocztowski, 2016). Ensuring fairness in remuneration systems is the foundation of their functioning under SHRM conditions (Kinowska, 2020). The research shows that fairness and transparent remuneration rules are popular actions undertaken in SHRM in Polish companies.

Combined with Green Human Resource Management (GHRM), the environmental dimension of SHRM aims to develop the ecological sensitivity of employees, ensuring awareness on how to protect the environment through their actions. Remuneration systems that support pro-ecological behaviour of employees include components rewarding for expected effects and attitudes; for example, awarding bonuses and prizes for the economical use of materials and machines, and sustainable development innovations implemented in the organisation (Pabian, 2017). Research shows that linking remuneration to the achievement of environmental objectives increases the effort to achieve them (May \& Flannery, 1995; Milliman \& Clair, 2013; Ramus, 2002). The effectiveness of this practice is confirmed by observations in highly polluting industries (Berrone \& Gomez-Mejia, 2009).

Subsequently, the development of appropriate remuneration systems is a challenge due to the difficulty of accurately assessing environmental behaviour and performance (Fernández, Junquera, \& Ordiz, 2003). Environmental competence can be a criterion for differentiating basic salaries (Brockett, 2007). Popular instruments to support environmental initiatives are discretionary awards - trips and diplomas, paid holidays, leisure time, parking spaces and gift vouchers (Govindarajulu \& Daily, 2004). Examples in the literature confirm that such practices motivate workers to develop environmental initiatives (Ramus, 2002). Errors in the design of remuneration systems can cause employees to avoid reporting environmental problems (Del Brío, Fernández, \& Junquera, 2007). Based on analyses of SHRM supporting practices, other authors have postulated research that identifies an effective approach to the design and implementation of remuneration systems that enable the achievement of environmental objectives (Jackson, Renwick, Jabbour, \& Muller-Camen, 2011). The following characteristics were distinguished in the pioneering analyses of remuneration systems within the SHRM: orientation and objectives, formalisation, performance orientation and flexibility (Radvila \& Šilingienè, 2020). Remuneration systems were analysed within the SHRM model, including the following characteristics: a longterm perspective, care for employees and the environment, profitability, employee participation or empowerment (employee involvement in decision-making processes), employee development, external partnership, flexibility, higher standards than required by labour law, cooperation and fairness and equality (Stankevičiute \& Savanevičiene, 2018). The complexity of the available models requires maturity of implementation of SHRM assumptions not available to organisations operating in Poland. 


\section{ENTREPRENEURSHIP AND SUSTAINABILITY ISSUES}

ISSN 2345-0282 (online) http://jssidoi.org/jesi/

2021 Volume 8 Number 4 (June)

http://doi.org/10.9770/jesi.2021.8.4(23)

Due to the limited presence of SHRM in Polish companies (Piwowar-Sulej, 2021), the article uses a conceptual framework combining the postulated features of remuneration systems with the general principles in the SHRM concept. The following remuneration characteristics supporting sustainable HRM are noted (Ehnert, Parsa, Roper, Wagner, \& Muller-Camen, 2016):

1) Taking into account the complexity of the relationship between the HRM system and the external and internal organisational environment manifested by linking the remuneration system to the business strategy and HRM in a way that enables their implementation;

2) Activities enabling the long-term reproduction of resources by supporting the long-term objectives of the organisation and addressing current challenges through reward systems;

3) Recognising and reconciling potentially conflicting economic, environmental and social objectives in remuneration systems.

\section{Impact of COVID-19 on the labour market in Poland}

The exploration of the use of sustainable development principles in enterprises operating in Poland under the conditions of the COVID-19 crisis requires understanding Poland's labour market. The Polish economy has the potential typical of this part of Europe. Polish GDP per capita in 2018 amounted to 12,400 EUR. It represented about $45 \%$ of the average GDP per capita for EU countries (Eurostat, 2019).

The analysis of social development is based on two main characteristics: the average salary and the wage gap between the highest and lowest earners. In Poland, the average salary is among the lowest in the EU (Reinis Fischer, 2019) although it is constantly growing. Its dynamics decreased due to the economic slowdown associated with the 2008 crisis (European Trade Union Institute, 2016). The low average salary reveals only a part of the problems Poland is facing. Another is a significant disproportion between the highest and the lowest earners. In Europe, there are significant inequalities in income distribution - the $20 \%$ of the population with the highest income in 2017 receives 5.1 times more income than the $20 \%$ of the population with the lowest income. In Poland, this indicator equals 4.1, which is slightly below the European average (Eurostat, 2019).

The effects of the COVID-19 pandemic were quickly reflected in the Polish labour market. The rate of registered unemployment in Poland in April 2020 was 5.7\% and increased by 0.3 p.p. compared to the previous month. In April 2020, a month after the beginning of the crisis, there were 964,800 unemployed registered in labour offices (55,400 more than a month earlier). The average monthly salary (gross) in the enterprise sector decreased by 3.7 p.p. compared to the previous month, and in April 2020, it amounted to 5,285.01 PLN. In April 2020, 57,500 vacancies were submitted to labour offices: 20,200 (26\%) less than in March 2020 (PARP, 2020).

\section{Research objective and methodology}

This study aims to reveal the characteristics of remuneration systems in Polish companies applying the SHRM framework, and to confirm the theoretical links between SHRM and remuneration systems by empirically assessing the expression of its principles in the characteristics of remuneration systems.

The methods of achieving this goal included a critical review of the source literature and diagnostic research. The study is based on qualitative data collected in 15 Polish organisations that declare sustainable development activities. The respondents were people responsible for shaping HRM functions in the organisation.

To achieve the research objectives, the following research questions were asked:

- What are the main features of remuneration systems in sustainable human resource management?

- How did these features manifest themselves in the COVID-19 crisis in Polish companies employing sustainable development principles?

The main research hypothesis adopted is that the characteristics of COVID-19 remuneration systems in sustainable organisations are in line with SHRM principles. 
In the first stage of the analysis, a systematic review of the literature was carried out. It takes into account research work on sustainable SHRM and related practices for remuneration schemes. Based on the literature review, the features of remuneration systems supporting the concept of sustainable HRM were formulated.

The second stage of the study presents the results of empirical observations. The complexity of the topic, the lack of existing data and the exploratory nature of the analysis required a qualitative approach. The research was carried out from June to August 2020, that is, in the period where business restrictions introduced in March 2020 due to the COVID-19 pandemic were gradually loosened in Poland. Organisations that publicly (in their annual reports or on their websites) declared sustainable development activities were invited to participate in the query. In total, 15 organisations agreed to participate in the research. Due to the execution of queries in times of COVID19 restrictions, all interviews were conducted using remote communication tools. The organisations analysed represented various industries in the private sector: manufacturing, trade, consulting and services. Board members supervising human resources functions and human resource managers were selected to provide comprehensive and accurate data as the analyses focused on the activities through which sustainable human resource management is implemented. Table 1 shows the profile of the organisation and the roles of the interviewing managers.

Table 1. Profile of organisations and respondents.

\begin{tabular}{|c|c|c|c|c|}
\hline Respondent number & Type of activity & $\begin{array}{l}\text { Number of } \\
\text { employees }\end{array}$ & Gender & $\begin{array}{l}\text { Role in the } \\
\text { organisation }\end{array}$ \\
\hline R1 & Consulting & $\begin{array}{l}\text { Approx. 6,000 } \\
\text { (Poland) }\end{array}$ & woman & HR expert \\
\hline $\mathrm{R} 2$ & High technology & $\begin{array}{c}\text { Approx. 1,000 } \\
\text { (Poland) }\end{array}$ & woman & HR Manager \\
\hline R3 & Finances & $\begin{array}{l}\text { Approx. } 4,000 \\
\text { (Poland) }\end{array}$ & woman & HR Director \\
\hline $\mathrm{R} 4$ & Production & $\begin{array}{l}\text { Approx. } 43,000 \\
\text { (world) }\end{array}$ & woman & HR Manager \\
\hline R5 & Consulting & $\begin{array}{l}\text { Approx. 8, } 900 \\
\text { (world) }\end{array}$ & $\operatorname{man}$ & $\begin{array}{c}\text { Talent \& } \\
\text { Development } \\
\text { Manager }\end{array}$ \\
\hline R6 & Production & $\begin{array}{c}\text { Approx. 3,000 } \\
\text { (Poland) }\end{array}$ & man & $\begin{array}{c}\text { HR Operations } \\
\text { Manager }\end{array}$ \\
\hline R7 & Hotel business & Approx. 10 (Poland) & $\operatorname{man}$ & The owner \\
\hline R8 & Consulting & $\begin{array}{c}\text { Approx. 1,000 } \\
\text { (Poland) }\end{array}$ & woman & Project Manager \\
\hline R9 & Production & $\begin{array}{l}\text { Approx. 200 } \\
\text { (Poland) }\end{array}$ & woman & HR Manager \\
\hline R10 & Production & $\begin{array}{l}\text { Approx. } 700 \\
\text { (Poland) }\end{array}$ & woman & HR Business Partner \\
\hline R11 & Finances & $\begin{array}{l}\text { Approx. 250 } \\
\text { (Poland) }\end{array}$ & woman & HR Manager \\
\hline R12 & Trade & $\begin{array}{l}\text { Approx. 1,800 } \\
\text { (Poland) }\end{array}$ & woman & HR Manager \\
\hline R13 & Consulting & $\begin{array}{l}\text { Approx. 2,000 } \\
\text { (Poland) }\end{array}$ & woman & HR Manager \\
\hline R14 & Pharmacy & $\begin{array}{l}\text { Approx. 2,500 } \\
\text { (Poland) }\end{array}$ & woman & HR Manager \\
\hline R15 & High technology & $\begin{array}{l}\text { Approx. 1,000 } \\
\text { (Poland) }\end{array}$ & woman & HR Manager \\
\hline
\end{tabular}

Source: the author.

In total, 15 semi-structured interviews were conducted. The interviews were conducted in Polish, recorded digitally and then transcribed. The guidelines for conducting interviews consisted of five groups of questions 


\section{ENTREPRENEURSHIP AND SUSTAINABILITY ISSUES}

ISSN 2345-0282 (online) http://jssidoi.org/jesi/

2021 Volume 8 Number 4 (June)

http://doi.org/10.9770/jesi.2021.8.4(23)

concerning selected practices of SHRM. For this article, the questions from the group on pay systems have been analysed, including a diagnosis of the remuneration system and the criteria for hiring employees concerned have changed following the COVID-19 pandemic crisis. The basic questions were supplemented with additional ones to improve the respondents' understanding of individual issues. The average duration of the interview was about one hour. To carry out the analysis, a theoretical code system based on the characteristics of SHRM was developed. The following procedure has been implemented: (1) preliminary examination of all interview transcripts for an overall assessment of their content; (2) multiple analyses of the transcripts and extraction of relevant statements; (3) condensation of extracted statements; (4) identification of practices based on the condensed statements; (5) extraction of groups of practices. The article presents results focusing on practices and their groups through which sustainable human resource management is expressed in the COVID-19 crisis remuneration systems.

\section{Results and discussion}

The aim of the qualitative component of this study is to explore the characteristics of remuneration systems supporting SHRM in Polish organisations in the COVID-19 crisis. Based on the analysis of the literature, four features of the remuneration system in SHRM were distinguished: (1) business pragmatism, (2) long-term orientation, taking into account (3) social and (4) environmental objectives. From the analysis of the interviews conducted within each of the characteristics, remuneration practices supporting the functioning of the analysed organisations during COVID-19 were identified. A grouping of similar practices was then carried out. The organisations under analysis declared the varied impact of the COVID-19 crisis on their operating possibilities and the generation of revenues and profits. The variability included: the need for a halt of operations and temporary lack of revenues (R7), changes in the production profile (R6), an increase in demand for selected services and a decrease in demand for others (R8) and the lack of impact of the crisis on the organisation (R13).

Research shows that the analysed companies were aware of the advantages of applying SHRM principles in times of crisis: "it was our company, thanks to this sustainable development, that was able to resist, to withstand the pressure of the difficulties of COVID" (R4). The first of the distinguished groups of remuneration practices were activities that testify to the business pragmatism of the examined organisations during COVID-19 (Table 2). Three types were distinguished: a systemic approach, communicating the package's value and monitoring attractiveness to employees.

Table 2. Remuneration practices related to business pragmatism

\begin{tabular}{|l|l|l|}
\hline Feature & \multicolumn{1}{|c|}{ Group of practices } & \multicolumn{1}{|c|}{ Practices during COVID-19 } \\
\hline Systemic approach & $\begin{array}{l}\text { - the use of the salary grid; } \\
- \text { basic salaries based on market levels; } \\
- \text { remuneration above market rates paid in the form } \\
\text { of an allowance for unique competences (possibility } \\
\text { of withdrawal during the crisis); } \\
- \text { variable parts depending on the performance of } \\
\text { business lines and the effects of individual } \\
\text { employees; } \\
\text { - allowing flexible adjustment of pay levels } \\
\text { depending on the impact of the crisis; }\end{array}$ \\
\cline { 2 - 4 } & $\begin{array}{l}\text { - the use of an online portal where the employee can } \\
\text { check the total value of the remuneration received } \\
\text { including cash and non-cash parts; } \\
\text { remuneration package }\end{array}$ \\
\cline { 2 - 4 } & $\begin{array}{l}\text { Monitoring attractiveness for } \\
\text { employees }\end{array}$ & $\begin{array}{l}\text { - modifications to the benefits package to choose } \\
\text { from within the cafeteria provided to employees. }\end{array}$ \\
\hline
\end{tabular}

Source: the author. 


\section{ENTREPRENEURSHIP AND SUSTAINABILITY ISSUES}

ISSN 2345-0282 (online) http://jssidoi.org/jesi/

2021 Volume 8 Number 4 (June)

http://doi.org/10.9770/jesi.2021.8.4(23)

The diagnosed organisations applied the structured principles of basic remuneration within the company's general salary grid:

"From a business perspective, it's a grid, there's an organisation, it's got its own chart of grades" (R9).

"For some time now, we've been moving within certain financial brackets for the given job" (R10).

The remuneration was determined based on target market remuneration levels:

"We've tried to make these salaries in our company equal to the market median in order to be competitive, or at least not to stand out from the market" (R10).

"We try to follow how the market pays, to be financially attractive to our candidates, to our employees" (R12).

"The assumption we made was that we wouldn't go below the market minimum wage, then finally it stood on average" (R15).

Possible deviations from market wage levels - resulting from the need to take into account the value of competences unique at a given moment in the labour market - were introduced in the form of wage supplements:

"Special qualification allowance; that is, you have a specific certification which causes your value in the market to be increased, because normally implementation consultants would earn $\mathrm{X}$, and because you have this specific certification, you are able to find a job in the market with higher money. Sometimes even 2x higher" (R2).

Such a solution allowed flexibility in regulating the remuneration during a pandemic. The formula of the bonus suggested to staff the reduced stability of this ingredient. It provided an opportunity to withdraw it during the crisis without reducing the basic salary. After the withdrawal of the allowance, the remuneration remained at the market level.

A common solution in the observed organisations was to use variable remuneration depending on individual, team and company performance. Thanks to this, depending on its impact on the organisation's results, automatically adjusting the level of the variable part became possible:

"How our bonus works, we'll know next March. Because then the effect of Covid and the whole year will have a direct impact on whether and who gets any bonus" (R2).

"We've got a year's target and there's a bonus over target. So, if you reach your goal, you still have to earn that bonus by generating a surplus" (R15).

Struggling with revenue drop, the organisations under analysis first introduced modifications to the bonus: "We have significantly reduced the number of people entitled to bonuses" (R3).

Focusing on changes in the variable part of pay made adapting the existing solutions to the different specificities of the work of individual teams during the COVID-19 crisis possible. It allowed organizations withdraw the bonus for supporting jobs and leave it for jobs that were dependent on individual performance and for which the bonus constituted a significant part of total remuneration: "New business bonus, supporting sales - stayed. It's not a bonus; it's a commission" (R15).

The organisations under study actively shaped employees' awareness of the total value of remuneration received including the fixed part, variable part and benefits:

"That if, for example, when it comes to wages, we're trying to show that you have such wages, but see, there's so many benefits that would cost you money if you wanted to purchase them. Often, employees forget that these benefits are $90 \%$ paid by the company. The company bears the costs" (R14).

"In general, we want to show the employee all the benefits he has from working for us by converting the benefits into market values" (R15).

In organisations where, due to the crisis, the structure of tasks performed by the HR unit changed and space for new initiatives appeared, additional time was spent on learning about the appeal of benefits for employees. Modifications were made based on the opinions of the employees: 


\section{ENTREPRENEURSHIP AND SUSTAINABILITY ISSUES}

ISSN 2345-0282 (online) http://jssidoi.org/jesi/

2021 Volume 8 Number 4 (June)

http://doi.org/10.9770/jesi.2021.8.4(23)

"A certain amount of breaks in some of the business areas that we had made people come back to us with feedback; how this system of non-wage benefits is perceived by them. And the very transformation that we're also doing in the HR field has given us space to change this system" (R5).

From the research results, it can be concluded that the analysed organisations applied a systematic approach to remuneration. They formalised remuneration systems. The wage grid was based on market levels. They benefited from extensive variable remuneration and benefit systems, calculated and communicated to the employees the value of the total remuneration package, monitored the attractiveness of benefits and modified them depending on employee feedback.

Sustainable HRM requires a long-term perspective. The research conducted revealed three groups of practices which prove its application in remuneration systems: protection of workplaces, the temporariness of changes and fulfilment of promises (Table 3).

Table 3. Remuneration practices that relate to the long-term perspective

\begin{tabular}{|c|l|l|}
\hline Feature & \multicolumn{1}{|c|}{ Group of practices: } & \multicolumn{1}{c|}{ Practices during COVID-19 } \\
\hline \multirow{3}{*}{ Long-term perspective } & Protection of workplaces & $\begin{array}{l}\text { - the use of unpaid leave by top earners; } \\
- \text { avoiding layoffs by temporarily transferring } \\
\text { employees to other tasks; } \\
- \text { sending employees on overdue leave; } \\
\text { - temporary reduction of working hours; }\end{array}$ \\
\cline { 2 - 3 } & Temporariness of changes & $\begin{array}{l}\text { - the rehiring of redundant workers under the same } \\
\text { conditions; } \\
\text { - a quick return to the pre-reduction salary; }\end{array}$ \\
\cline { 2 - 3 } & $\begin{array}{l}\text { - to carry out the basic salary increases promised to } \\
\text { employees before the pandemic; }\end{array}$ \\
\hline
\end{tabular}

Source: own study.

The employers under analysis were aware of the two-sided benefits of long-term relationships with employees: "An indefinite contract is such a guarantee for employees with whom we are bound for more than a year. Because it also gives them some guarantee that we're not about to part with them when the contract ends, they can look to the future safely" (R7).

In cases of financial problems resulting from the COVID-19 crisis, some employees were encouraged to reduce their working hours to avoid or postpone the need to terminate contracts:

"Part of this restructuring is to tell people: come forward to reduce your working hours by $20 \%$ until the end of the year" (R2).

To avoid redundancies, employers sent employees on overdue leave and shifted them to tasks that were increasing in number due to the effects of the pandemic:

"Initially, in the first phase of the pandemic, we used to send employees on leave. If the form of the leave was exhausted, unfortunately, we had to part with some" (R7);

"Teams appeared (...) where, due to the nature of our industry, there was 300\% more work than usual. And we needed hands to work. And that was the moment: 'Okay, here it is, because there are no new contracts, we're moving you to the collection department"“ (R11).

Where there was a need to carry out salary reductions, the organisations concerned made effort to return to the status quo as soon as possible: 


\section{ENTREPRENEURSHIP AND SUSTAINABILITY ISSUES}

ISSN 2345-0282 (online) http://jssidoi.org/jesi/

2021 Volume 8 Number 4 (June)

http://doi.org/10.9770/jesi.2021.8.4(23)

"There have been some measures taken in our company to reduce the salary, but temporary, in those business areas that have indeed been most affected by the pandemic and pandemic-related crisis. Now we're in July, I mean we're in August, but since the beginning of July, we've basically returned to the pre-crisis situation" (R4). "At the end of June, we return to standard rules and tasks. And the way of accounting" (R6).

An important value for the companies analysed was the fulfilment of the promises made regarding remuneration. The pay raises promised to employees at the beginning of the year were implemented despite the deterioration of the company's financial situation:

"We implemented pay raises in April. That too, we even wondered if we would have permission for employee raises. In our case it is funny because we are making raises retrospectively from the first of January, although sometimes decisions are made in March, and as in our case, it was in April, when the crisis was bustling around the world. But we implemented the pay raises; employees received the pay raises. They were very pleased with it" (R4).

In conclusion, the examined organisations took into account the long-term effects when establishing remuneration decisions in a crisis. Because they were aware of the impact of long-term relationships with employees and the fulfilment of their pay promises, they protected jobs and quickly restored pre-crisis conditions. Social orientation, which is important for SHRM, was included in the remuneration systems when wages were reduced, and these organisations granted their employees compensation for working in close contact with other people during the pandemic (Table 4).

Table 4. Remuneration practices taking into account social orientation

\begin{tabular}{|l|l|l|}
\hline Feature & Group of practices & Practices during COVID-19 \\
\hline Social orientation & $\begin{array}{l}\text { Taking into account remuneration } \\
\text { levels in remuneration reductions } \\
\text { - voluntary participation in reductions by encouraging } \\
\text { to the use of unpaid leave only by top earners; } \\
- \text { in the case of changes in variable salaries (bonuses, } \\
\text { allowances), maintaining them for the lowest earners; }\end{array}$ \\
\cline { 2 - 4 } & $\begin{array}{l}\text { Additional remuneration for work in } \\
\text { the company at the time of closure of } \\
\text { the economy }\end{array}$ & $\begin{array}{l}\text { - allowances for coming to work during a pandemic; } \\
- \text { - guarantion of paying a bonus for 3 months from the } \\
\text { beginning of the crisis regardless of the results; } \\
\text { - reduction in the working hours of production } \\
\text { workers while maintaining full-time wages. }\end{array}$ \\
\hline
\end{tabular}

Source: the author.

The queried organisations took into account the level of remuneration received. Wage reductions were limited to the highest earners, who were encouraged to take unpaid leaves:

"All better-paid employees of our company have been asked to volunteer to take a week of unpaid leave" (R2). Efforts were made to ensure that the withdrawal of salary supplements, reductions in the fixed part and bonuses were less severe for the lesser earners:

"Those who earn less will be included. This allowance will be included in the basic salary, but the extra policy is out, and those who earn better will simply lose" (R2). 


\section{ENTREPRENEURSHIP AND SUSTAINABILITY ISSUES}

ISSN 2345-0282 (online) http://jssidoi.org/jesi/

2021 Volume 8 Number 4 (June)

http://doi.org/10.9770/jesi.2021.8.4(23)

"Unfortunately, we had a $20 \%$ reduction under the shield along with a reduction in working hours. Of course, we made the assumption that we do not go below the minimum market wage, then we finally decided it will be average wage, so there are groups here that had a 10\% reduction, not 20\%" (R15).

Organisations that required their employees to be present at the workplace at the time of the closure of the economy offered them extra pay. Solutions included the reduction of working hours while retaining wages, pay and bonus allowances, and compensation for sickness benefit or care allowance related to COVID:

"As early as in March, we offered our employees three very important things: a work allowance, a guarantee of employment for three months, equalisation of bonuses and allowances for people who had to go for care allowance because they had children or were sick and it was COVID-related. It was the XYZ that was supplementing the $100 \%$ salary" (R6).

"A COVID bonus for workers in production who do not work eight hours, only six hours, being paid in full so that they do not feel discriminated against office workers" (R9).

To sum up the inclusion of a social orientation in wages, the use of social criteria in the changes resulting from the COVID-19 crisis should be noted. These criteria took into account both companies whose operating conditions deteriorated and those that could continue to operate. The organisations surveyed reduced basic salaries so that the changes affected the lowest earners the least. When it was necessary to work in contact with colleagues during the pandemic, companies compensated their employees for the inconvenience.

An important aspect of sustainable development was the inclusion of environmental orientation in remuneration systems. The research shows that during the COVID-19 pandemic, companies paid relatively little attention to environmental orientation. It manifested only when employers financed charity organisations from the remuneration received or exchanged the pool of funds earmarked for benefits to support the charity (Table 5):

Table 5. Remuneration practices taking into account environmental orientation

\begin{tabular}{|l|l|l|}
\hline Feature & Group of practices & Practices during COVID-19 \\
\hline Eco-orientation & $\begin{array}{l}\text { Supporting the financing of charitable } \\
\text { organisations }\end{array}$ & $\begin{array}{l}- \text { the possibility of paying contributions from wages } \\
\text { to the chosen charity and doubling this amount by the } \\
\text { employer; }\end{array}$ \\
\hline
\end{tabular}

Source: the author.

Employers introduced changes to benefit systems, allowing funds to be used for charitable purposes instead of the purchase of goods and services for employees:

"People, for example, have told us that they lack the ability to donate some of the points that go from their employer to charity - for a charity of their choice. So, we decided to change the benefit provider and the system itself from next year on, so that our employees can do that" (R5).

An alternative solution was for the company to mediate in the regular financing of charitable activities by deducting, at the request of the employee, the amount from the salary and subsidising the supported organisation by the employer:

"Any employee may sign such a declaration and agree to the deduction of an amount from his or her monthly salary for the benefit of this programme (...). And that money is accumulated in the account. When a need arises, whether in Poland, the Czech Republic, Serbia or some other continent, then this organisation, which manages the funds, takes a certain amount of money from the available ones, informs everyone what the money is spent on, and $\mathrm{XYZ}$ adds twice as much" (R4). 


\section{ENTREPRENEURSHIP AND SUSTAINABILITY ISSUES}

ISSN 2345-0282 (online) http://jssidoi.org/jesi/

2021 Volume 8 Number 4 (June)

http://doi.org/10.9770/jesi.2021.8.4(23)

The results showed that the environmental aspect of the COVID-19 crisis was relatively the least significant of the dimensions analysed. It was limited to relatively small gestures supporting employees’ initiative.

\section{Discussion of the results}

Most of the publications available in the literature on SHRM remuneration schemes are descriptive. They lack empirical research. Qualitative research that allows for the identification of key aspects of the structures under analysis is rare. The analyses of the relationship between changes in remuneration systems resulting from the COVID-19 crisis and sustainable HRM is pioneering. They confirm the effectiveness of the application of sustainability principles in remuneration systems and provide insight into the sustainability of the management concepts adopted.

The results confirm the validity of Radvila and Šilingienè's (2020) statements during the COVID-19 crisis. According to their observations, the dimensions of SHRM are reflected in objectives, performance orientation and flexibility of remuneration schemes. The indicated characteristics are present in solutions implemented during the pandemic in all observed dimensions: business pragmatism, long-term orientation and combining economic, social and environmental aspects.

Empirical observations carried out confirmed the model of characteristic features of SHRM practises during the COVID-19 crisis (Stankevičiute \& Savanevičiene, 2018). They include care for employees, profitability, external partnership, fairness and equality and development of employees. The remuneration systems in the COVID-19 era show that the focus of the analysed organisations was on caring for employees through the application of solutions aimed at protecting workplaces, compensating for the pandemic and minimising the nuisance of salary reductions. Fairness and equality were manifested in the consistent application of the adopted solutions to groups of employees, taking into account the level of remuneration when taking adverse measures for employees, employee opinions on their benefits and introducing solutions to support social initiatives.

I

$\mathrm{n}$ the Stankevičiūtè and Savanevičienè studies (2018), a long-term orientation was among the characteristics moderately present in SHRM. Analyses of the remuneration systems during the COVID-19 indicate that this dimension is significant in a crisis.

The results of the research support the claim that sustainability at the level of HRM systems is a complex, multifaceted design (Ehnert \& Harry, 2012). It covers environmental, social and economic aspects. The analyses also confirmed the presence of all three dimensions of sustainability in the remuneration systems during the COVID19 crisis. The ideas of sustainable economic, social and environmental development are implemented through separate characteristics of the remuneration system. Empirical observations have revealed how the commitment to the principles of sustainability has shaped the responses of companies to the COVID-19 crisis remuneration systems.

\section{Conclusions}

The article provides empirical insights into the remuneration system in SHRM during the COVID-19 crisis. The value of the article is based on empirically proven characteristics of the remuneration system, drawing relations to SHRM attributes. The added value of empirical research includes disclosure of the components of remuneration systems that contribute to SHRM in the COVID-19 crisis. 


\section{ENTREPRENEURSHIP AND SUSTAINABILITY ISSUES}

ISSN 2345-0282 (online) http://jssidoi.org/jesi/

2021 Volume 8 Number 4 (June)

http://doi.org/10.9770/jesi.2021.8.4(23)

The novelty of the reserach is the identification of specific characteristics and practices of remuneration systems in all analysed dimentions of sustainable management:

1) Taking into account the complexity of relations between the HRM system and the external and internal organisational environment in connection with the remuneration system with the business strategy and HRM. The research shows that on implementation, this manifests as the focus on a systemic approach to remuneration, communicating the value of the remuneration package and monitoring its value for employees;

2) Activities enabling the long-term reproduction of resources by supporting both the long-term objectives of the organisation through remuneration systems and addressing current challenges. The study points to the particular importance of protecting jobs, the temporariness of changes (in particular deterioration due to the crisis) and keeping wage promises;

3) Recognising and reconciling potentially conflicting objectives in remuneration systems: economic, environmental and social. Reserch shows that this dimention has manifested itself in taking account of the social perspective in wage reductions and compensating for the need to work at a time when the economy is closed, including the possibility of supporting charities in the remuneration systems.

The conducted analyses fill the research gap in the the design of remuneration systems supporting SHRM. The research has shown the existence of a set of specific characteristics of remuneration systems typical of SHRM. Their importance is particularly evident during the COVID-19 crisis. The increased popularity of SHRM concept should contribute to further research into supporting practices in particular remuneration schemes. Further quantitative analyses are needed to confirm the links between solutions and sustainable management features, as well as the identification of good practices to promote the implementation of the SHRM model in organisations.

\section{Research limitations}

Although this research makes important theoretical and empirical contributions to the existing literature, some limitations must be kept in mind. The main empirical contribution of this article is drawing attention to characteristics of remuneration systems supporting SHRM. The COVID-19 crisis was used as a case study. The in-depth interviews were conducted during the first wave of the pandemic. The crisis has consequences on many levels - in the economy, the labour market, the education, the ability of organisations to carry out their activities and employees to work. The sudden and acute nature of the crisis highlighted the characteristics of organisational solutions. It was a verification of their commitment to the declared principles of sustainable development. The difficult and unexpected market situation highlighted the characteristics of remuneration systems. Their specificity is, on the one hand, linked to the reaction to the crisis and, on the other hand, contains features which may be also universal in post-crisis times.

The respondents in the in-depth interviews were limited to employers from Poland. They represented a diverse range of organisations pledging to act in accordance with the principles of sustainable development. The identified characteristics of remuneration systems were present in both local and international organisations participating in the study. Therefore, it can be concluded that the described research results may also be of importance in the international discourse. Some limitation may be the intentional selection of the research sample, which preclude the generalization of the obtained results.

Certainly, this issue requires further research, especially with regard to the universal characteristics and design of remuneration systems in SHRM. Quantitative research should be considered as the next research step that allows to deepen the obtained results. The quantitative analysis could help to reliably estimate how the characteristics and components of remuneration systems affect the sustainable management in the organisations. 


\section{ENTREPRENEURSHIP AND SUSTAINABILITY ISSUES}

ISSN 2345-0282 (online) http://jssidoi.org/jesi/

2021 Volume 8 Number 4 (June)

http://doi.org/10.9770/jesi.2021.8.4(23)

\section{References}

Armstrong, M., \& Taylor, S. (2017). Armstrong's handbook of human resource management practice. 14th edition. In London: KoganPage.

Berrone, P., \& Gomez-Mejia, L. R. (2009). Environmental performance and executive compensation: An integrated agency-institutional perspective. Academy of Management Journal. https://doi.org/10.5465/AMJ.2009.36461950

Brockett, J. (2007). Prepare Now for Big Rise in Green Jobs. People Management, (17th May).

Del Brío, J. Á., Fernández, E., \& Junquera, B. (2007). Management and employee involvement in achieving an environmental action-based competitive advanrage: An empirical study. International Journal of Human Resource Management. https://doi.org/10.1080/09585190601178687

Diaz-Carrion, R., López-Fernández, M., \& Romero-Fernandez, P. M. (2018). Developing a sustainable HRM system from a contextual perspective. Corporate Social Responsibility and Environmental Management. https://doi.org/10.1002/csr.1528

Ehnert, I., \& Harry, W. (2012). Recent Developments and Future Prospects on Sustainable Human Resource Management: Introduction to the Special Issue. Management Revu. https://doi.org/10.5771/0935-9915-2012-3-221

Ehnert, I., Parsa, S., Roper, I., Wagner, M., \& Muller-Camen, M. (2016). Reporting on sustainability and HRM: a comparative study of sustainability reporting practices by the world's largest companies. International Journal of Human Resource Management. https://doi.org/10.1080/09585192.2015.1024157

European Trade Union Institute. (2016). Benchmarking Working Europe 2016. ETUI. Retrieved from https://www.etui.org/publications/books/benchmarking-working-europe-2015

Eurostat. (2019). Income poverty statistics. In Statistics Explained. Retrieved from https://ec.europa.eu/eurostat/statisticsexplained/index.php?title=Income_poverty_statistics\#At-risk-of-poverty_rate_and_threshold

Fernández, E., Junquera, B., \& Ordiz, M. (2003). Organizational culture and human resources in the environmental issue: A review of the literature. International Journal of Human Resource Management. https://doi.org/10.1080/0958519032000057628

Flannery, T. P., Hofrichter, D. A., \& Platten, P. E. (1996). People, Performance and Paye. New York: Free Press.

Govindarajulu, N., \& Daily, B. F. (2004). Motivating employees for environmental improvement. Industrial Management and Data Systems. https://doi.org/10.1108/02635570410530775

Guest, D. E. (2011). Human resource management and performance: Still searching for some answers. Human Resource Management Journal. https://doi.org/10.1111/j.1748-8583.2010.00164.X

Jackson, S. E., Renwick, D. W. S., Jabbour, C. J. C., \& Muller-Camen, M. (2011). State-of-the-art and future directions for green human resource management. German Journal of Research in Human Resource Management. https://doi.org/10.1688/1862-0000

Juchnowicz, M. (2012). Zaangażowanie pracowników. Sposoby oceny i motywowania (Employee engagement. Ways of evaluation and motivation). Warsaw: PWE.

Juchnowicz, M. (2019). Zwinne organizacje wyzwaniem dla zarządzania kapitałem ludzkim (Agile organisations - a challenge for human capital management). Zarzadzanie Zasobami Ludzkimi (Human Resource Management), 2(127), 43-55. Retrieved from https://www.ipiss.com.pl/?zzl=zwinne-organizacje-wyzwaniem-dla-zarzadzania-kapitalem-ludzkim

Kinowska, H. (2020). The Perception of Fair Remuneration as a Component of Sustainable Development. Edukacja Ekonomistów $i$ Menedżerów. https://doi.org/10.33119/eeim.2020.56.6

Lawler, E. E. (1990). Strategic Pay. San Francisco: Jossey-Bass.

May, D. R., \& Flannery, B. L. (1995). Cutting waste with employee involvement teams. Business Horizons. https://doi.org/10.1016/00076813(95)90033-0

Milkovich, G. T., Newman, J. M., \& Gerhart, B. (2014). Compensation. New York: McGraw-Hill/Irwin.

Milliman, J., \& Clair, J. (2013). Best Environmental HRM Practices in the US. In Greening People: Human Resources and Environmental Management. https://doi.org/10.9774/gleaf.978-1-909493-00-1_4

Pabian, A. (2017). Zrównoważone zarządzanie zasobami ludzkimi - zarys problematyki (Sustainable human resources management - an overview). Zeszyty Naukowe Politechniki Częstochowskiej (Scientific Journal of the Częstochowa University of Technology), 17, 716. Retrieved from http://bazekon.icm.edu.pl/bazekon/element/bwmeta1.element.ekon-element-000171396555

PARP. (2020). Rynek pracy, edukacja, kompetencje. Aktualne trendy i wyniki badań (marzec 2020) (Labour market, education, competences. Current trends and research results (March 2020)). Retrieved from https://www.parp.gov.pl/component/publications/publication/rynek-pracy-edukacja-kompetencje-marzec-2020-3-1

Piwowar-Sulej, K. (2021). Human resources development as an element of sustainable HRM - with the focus on production engineers. Journal of Cleaner Production. https://doi.org/10.1016/j.jclepro.2020.124008

Pocztowski, A. (2016). Zrównoważone zarządzanie zasobami ludzkimi w teorii i praktyce (Sustainable human resource management in theory and practice). Zarządzanie i Finanse (Journal of Management and Finance), 14(2), 303-314.

Poškiene, E. (2014). Sustainability Perspective in the Human Resource Management and Organizational Performance Linkage. Uncertainty in a Flattening World: Challenges for IHRM, Book of Abstracts. Cracow.

Radvila, G., \& Šilingienè, V. (2020). Designing Remuneration Systems of Organizations for Sustainable HRM: The Core Characteristics of an Emerging Field. International Journal of Human Resource Studies. https://doi.org/10.5296/ijhrs.v10i2.17086

Ramus, C. A. (2002). Encouraging innovative environmental actions: What companies and managers must do. Journal of World Business. https://doi.org/10.1016/S1090-9516(02)00074-3

Reinis Fischer. (2019). Average Salary in European Union 2018 | Reinis Fischer. Retrieved from Reinis Fischer website: 


\section{ENTREPRENEURSHIP AND SUSTAINABILITY ISSUES}

ISSN 2345-0282 (online) http://jssidoi.org/jesi/

2021 Volume 8 Number 4 (June)

http://doi.org/10.9770/jesi.2021.8.4(23)

https://www.reinisfischer.com/average-salary-european-union-2018

Schuster, J. R., \& Zingheim, P. K. (1992). The New Pay. New York: Jossey-Bass.

Stankevičiute, Ž., \& Savanevičiene, A. (2018). Designing sustainable HRM: The core characteristics of emerging field. Sustainability (Switzerland). https://doi.org/10.3390/su10124798

Wang, T., Zhao, B., \& Thornhill, S. (2015). Pay dispersion and organizational innovation: The mediation effects of employee participation and voluntary turnover. Human Relations. https://doi.org/10.1177/0018726715575359

Westerman, J. W., Rao, M. B., Vanka, S., \& Gupta, M. (2020). Sustainable human resource management and the triple bottom line: Multistakeholder strategies, concepts, and engagement. Human Resource Management Review.

https://doi.org/10.1016/j.hrmr.2020.100742

\section{Acknowledgements}

This research was carried out within the framework of the Statutory Research for 2019-2021 of the Collegium of Business Administration, SGH Warsaw School of Economics "Enterprise in the face of sustainable development requirements".

Hanna KINOWSKA is Assistant Professor at the Institute of Human Capital at SGH Warsaw School of Economics. Sheholds a PhD in economics. She islecturer, author of many publications on human capital management. Associated with practice, she has carried out numerous projects improving human capital management, especially in the areas of remuneration systems and employee engagement.

ORCID ID: orcid.org/0000-0002-7936-9737

Register for an ORCID ID:

https://orcid.org/register

Make your research more visible, join the Twitter account of ENTREPRENEURSHIP AND SUSTAINABILITY ISSUES: @Entrepr69728810

Copyright (C) 2021 by author(s) and VsI Entrepreneurship and Sustainability Center

This work is licensed under the Creative Commons Attribution International License (CC BY).

http://creativecommons.org/licenses/by/4.0/

(c) (i) Open Access 